\section{Triops granarius (Lucas) (Crustacea) as a Natural Enemy of Mosquito Larvæ}

Literature on the natural enemies of mosquitoes reviewed by Hinman ${ }^{1-3}$, contains little to suggest that crustaceans are of much significance as biological control agents. Therefore, and in view of the fact that there is renewed interest in biotic factors in vector control ${ }^{4}$, this communication may stimulate others to pursue the matter further than I can.

El Bur $\left(4^{\circ} 41^{\prime}\right.$ N., $46^{\circ} 36^{\prime} \mathrm{E}$.) in the Mudugh plain of central-northern Somalia is a village of about 300 huts placed on a small elevation above a depression in which some shallow wells have been dug. 'The climate is typical of the region with a total of about $10 \mathrm{in}$. rain falling during A.pril-May ( $g u$ rains) and Septomber-November (der rains).

In $1956 \mathrm{El}$ Bur was visited by the Somalia National Malaria Service during the gu rains when 15-20 adult Anopheles gambiae per room were caught by hand. An attempt to find larvæ either in the wells or in a large shallow depression which had filled with rain water, however, was unsuccessful. This was the more puzzling since no other water suitable as breeding places was anywhere to be found.

During this search it was noted that the water along the whole fringe of the depression was swarming with a large crustacean later kindly identified for me by Mr. Longhurst of the British Museum as Triops granarius (Lucas) (Fig. 1). It seemed that the presence of this crustacean corresponded with the absence of larvæ and this was afterwards confirmed by numerous other observations in Mudugh and Mijustinia during 1956-59, as, for example, at the villages of Adado, 1956-57, Sinadogo 1957, El Bur 1957-59, Mataban 1957, Salahdadab 1957, Goffafo 1957, Mirrich 1957-59 (Maffi 1960) ${ }^{5}$. In Sinadogo, Mirrich and Adado it was particularly noticeable that those wells which had mosquito larvæ contained no Triops. Such wells were separated by only a few metres from wells with Triops and no mosquito larvæ.

At no time were Triops actually caught in the act of catching or devouring mosquito larvæ, but the possibility that they do so or in some way make the water unattractive or uninhabitable for mosquito larvæ cennot be dismissed.

Longhurst ${ }^{6}$ indicates that Triops usually occur in temporary pools and that the eggs show great powers of resisting desiccation. In Somalia, Triops are mostly found in exposed shallow collections of still and muddy water without vertical vegetation and in

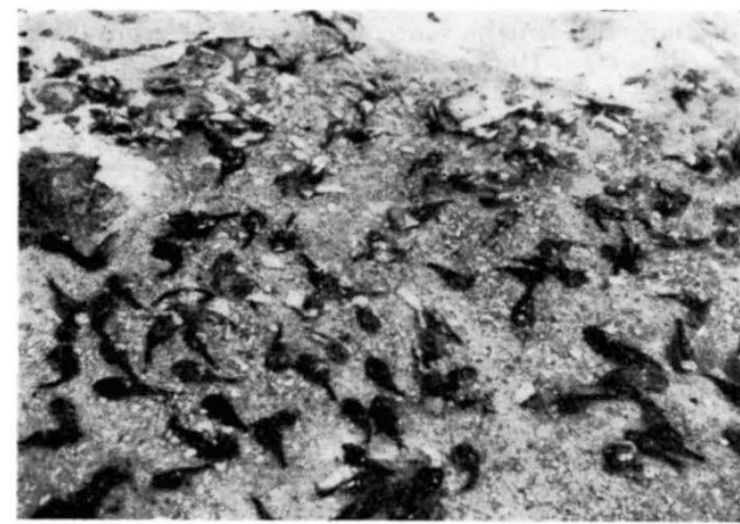

Fig. 1. Triops granarius along the margin of a shallow pool at El Bur, Somalia, 1956 shallow wells, its habitats thus presenting conditions highly favourable for $A$. gambiae.

Though the evidence is far from conclusive it is obvious that the matter merits further study. The particular characteristics of Triops which are of interest to the sanitarian are, of course, the ability of the eggs to withstand desiccation and the preferential breeding places which coincide so nicely with those of Anopheles gambiae.

\section{P.O. Box 8067}

Mario Mafri*

Causeway, Salisbury,

Southern Rhodesia.

* Formerly, Somalia National Malaria Service, Mogadishiu, Somalia. Hinman, E. H., J. Trop. Med. Hyg., 37, 129, 145 (1934).

Bates, M. Natural History of Mosquitoes, 738 (Macmillan Co., New York, 1954).

${ }^{3}$ Horsfall, W. R., Mosquitoes, Their Bionomics and Relation to Disease, 723 (Ronald' Press Co., New York, 1955).

${ }^{4}$ Laird, M., Acta Trop. (Basel), 16, 331 (1959).

- Maffi, M., Riv. Malar., 39, 21 (1960).

- Longhurst, A. R., Bull. Brit. Mus. (Nat. Hist.) Zoology, 3 (1) (1955).

\section{Maturation of Schistosome Eggs in vitro}

EgG-LAYING in vitro by Schistosoma japonicum and $S$. mansoni in serum media was not described by early investigators ${ }^{1-4}$, and presumably did not occur. Later it was reported that a few eggs were laid when flukes were kept for up to two months in a glass apparatus with provision for daily (hange of medium (horse serum) ${ }^{5}$. A method of maintaining S. mansoni flukes so that a regular output of $30-40$ eggs a day was obtained has recently been published ${ }^{6-8}$. Some cell division was seen, but the eggs did not mature in serum media, saline or 'Tyrode's solution.

During experiments in which $S$. mansoni pairs were kept in whole blood continuously dialysed against serum, some mature eggs were found after 15 days, and a few hatched out apparently normal miracidia. After further investigation, it became clear that the presence of blood cells assisted maturation and that eggs were laid and would mature in medium consisting of one part of serum, two parts of Tyrode's solution and a small addition of red and white cells; dialysis of the medium was not necessary. Attempts were then made to obtain enough miracidia to infect snails.

Paired S. japonicum and $S$. mansoni flukes were removed from portal veins of infected hamsters and placed in Carrel flasks containing $3 \mathrm{ml}$. of a guinea pig serum/Tyrode medium ( $1: 2$ ) with added glucose, streptomycin and penicillin. This had proved to be the best medium for regular egg production ${ }^{8}$. Five to nine days later, when eggs had been laid, the medium was changed to human serum/Tyrode with a few drops of buffy coat. Full sterile precautions were observed. Although many eggs were produced and cell-division began, none reached maturity, and the medium was clearly unsatisfactory.

In spite of the pre-eminence of guinea pig serum, it was decided to keep japonicum flukes in human serum/Tyrode $(3: 10)$ and mansoni flukes in baboon serum/Tyrode $(3: 10)$ with added glucose $(2 \mathrm{mgm} . / \mathrm{ml}$.) and penicillin and streptomycin (100 units $/ \mathrm{ml}$.). One pair was incubated at $37^{\circ} \mathrm{C}$. in each 6 in. $\times \frac{3}{4}$ in. tube containing $5 \mathrm{ml}$. of medium. Tubes were opened after 14-17 days and the eggs recovered, washed well in saline and hatched in tap water in a watch glass.

Twenty to thirty miracidia were obtained from each S. japonicum tube and at least 30 from each S. mansoni 